
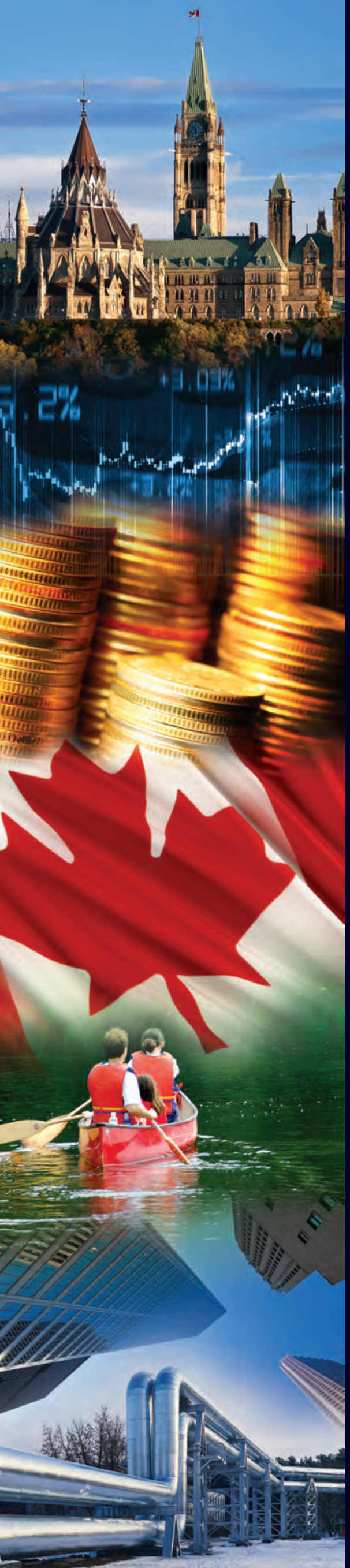

\section{COMMENTARY}

NO. 464

\title{
The Art of Breaking the Deal: What President Trump Can and Can't Do About NAFTA
}

While the president's anti-NAFTA rhetoric has been directed at offshoring and balance-of-payments issues with Mexico, Canada is at risk of being sideswiped by aggressive anti-trade and anti-NAFTA measures that the president may adopt.

Jon R. Johnson 


\section{THE INSTITUTE'S COMMITMENT TO QUALITY}

\section{ABOUT THE AUTHOR}

Jon R. JoHnson was an advisor to the Canadian government during the NAFTA negotiations and is the author of The North American Free Trade Agreement: A Comprehensive Guide, Canada Law

Book Inc., 1994.
Commentary No. 464

January 2017

Trade and International Policy
C.D. Howe Institute publications undergo rigorous external review by academics and independent experts drawn from the public and private sectors. The Institute's peer review ensures the quality, integrity and objectivity of its policy research. The Institute will not publish any study that, in its view, fails to meet these standards.

The Institute requires that its authors publicly disclose any actual or potential conflicts of interest of which they are aware.

In its mission to educate and foster debate on essential public policy issues, the C.D. Howe Institute provides nonpartisan policy advice to interested parties on a non-exclusive basis. The Institute will not endorse any political party, elected official, candidate for elected office, or interest group.

As a registered Canadian charity, the C.D. Howe Institute as a matter of course accepts donations from individuals, private and public organizations, charitable foundations and others, by way of general and project support. The Institute will not accept any donation that stipulates a predetermined result or policy stance or otherwise inhibits its independence, or that of its staff and authors, in pursuing scholarly activities or disseminating research results.
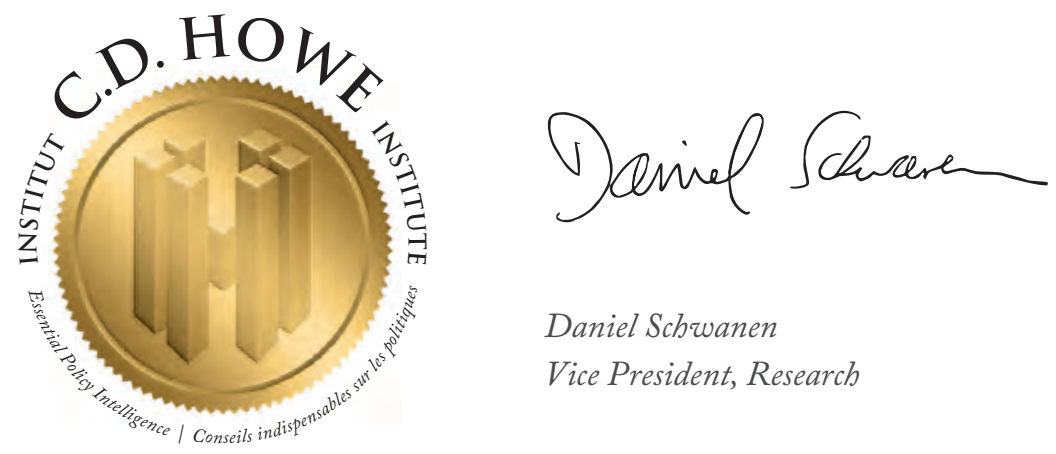

Daniel Schwanen

Vice President, Research 


\section{THE STUDY IN BRIEF}

President-elect Trump has repeatedly said that he could tear up NAFTA. Can the president unilaterally cause the US to withdraw from NAFTA or must Congress agree? Congress must concur because the president and Congress have joint authority over trade agreements. However, unless Congress actively resists a presidential attempt to unilaterally withdraw from NAFTA, the US courts will not intervene, underscoring the importance to Canada of working closely with Congress.

Further, the president has the power to frustrate NAFTA by taking various executive actions. While the sole power to impose duties under the US Constitution rests with Congress, Congress has delegated powers to the president to act unilaterally to address national emergencies and balance-of-payments and national security situations. These powers include the ability to raise tariffs and to adopt other border measures. The exercise of such powers could be very costly to the US economy and would doubtless provoke retaliation from US trading partners and litigation both in the US court system and before international bodies such as the WTO.

While the president's anti-NAFTA rhetoric has been directed at offshoring and balance of payments issues with Mexico, Canada is at risk of being sideswiped by aggressive anti-trade and anti-NAFTA measures that the president may adopt. Canada must be prepared to renegotiate NAFTA with the US administration, preferably on a trilateral basis that includes Mexico. However, the Canadian government must also exercise its rights under international trade agreements. The governments of Canada and Mexico need to secure support in Congress. Members of the House and Senate will be sensitive to damage to US businesses and job loss in their congressional districts and in their home states caused by the adoption of punitive trade measures.

C.D. Howe Institute Commentary $(\mathrm{C}$ is a periodic analysis of, and commentary on, current public policy issues. James Fleming edited the manuscript; Yang Zhao prepared it for publication. As with all Institute publications, the views expressed here are those of the author and do not necessarily reflect the opinions of the Institute's members or Board of Directors. Quotation with appropriate credit is permissible.

To order this publication please contact: the C.D. Howe Institute, 67 Yonge St., Suite 300, Toronto, Ontario M5E 1J8. The full text of this publication is also available on the Institute's website at www.cdhowe.org. 


\section{During the US election campaign, now President-elect Donald Trump repeatedly described the North American Free Trade Agreement ("NAFTA") as the "worst trade agreement ever" and vowed that he would renegotiate it or "tear it up."}

By “tearing up NAFTA” Mr. Trump presumably meant that he would cause the United States to withdraw from NAFTA unless his demands in a renegotiation were met. The main question I examine here is whether the president can trigger a withdrawal of the United States from NAFTA without the concurrence of Congress. This raises important issues for the governments of Canada and Mexico and for all private-sector entities and persons whose prosperity depends on the continued existence of NAFTA. This paper draws implications specifically for the government of Canada. The discussion is organized around five questions:

1. Can the president unilaterally withdraw the US from NAFTA?

2. Can the president unilaterally raise trade duties on NAFTA partners by proclamation?

3. When and how can Congress defend its powers?

4. What other presidential powers could be used to frustrate NAFTA?

5. The focus on Mexico - What are the implications for Canada?

1. CAN THE PRESIDENT UNILATERALLY WITHDRAW THE US FROM NAFTA?

The ultimate threat President Trump can make in a NAFTA renegotiation if his demands are not met is for the United States to withdraw from the trade deal. While there are many ways in which the Trump Administration could proceed to achieve its trade objectives as regards NAFTA, the governments of Canada and Mexico should regard the US threat of withdrawal as a possibility and determine the steps required for the US government to make good on this threat.

The NAFTA text itself contemplates that a NAFTA Party may wish to withdraw from NAFTA. Article 2205 provides that a Party may withdraw from NAFTA six months after providing written notice of withdrawal to the other Parties. However, giving the notice in and of itself does not give effect to such a withdrawal.

Indeed, as I show here, Congress must concur if the government of the United States is to formally withdraw from NAFTA.

However, as will be discussed later in this paper, the president has powers delegated to him by Congress that he could use to seriously frustrate the operation of NAFTA and force concessions from the governments of the other NAFTA Parties. The governments of Canada and Mexico should examine the scope of each of these powers and the degree to which the application of each is subject to constraint by the US Congress or by the US Courts, before deciding on a course of action in the face of any presidential declaration to seek to renegotiate or withdraw from NAFTA. 


\section{The President's Foreign Affairs Powers versus Congressional Trade Powers}

In the first of a useful series of studies published by the Peterson Institute under the title Assessing Trade Agendas in the US Presidential Campaign ${ }^{1}$ (the "Peterson study"), the Peterson Institute's Gary Clyde Hufbauer states that the president could use "the foreign affairs powers of the President to terminate NAFTA". ${ }^{2}$ The Economist magazine has picked up this conclusion with the statement: "He [President Trump] could use the President's prerogative over foreign affairs to withdraw from the North American Free Trade Agreement with just six months' notice according to the Peterson Institute, a think tank."

Would withdrawal be that straightforward? Not when we examine the extent of the foreign affairs powers of the President under the US Constitution and the manner in which these powers interact with powers granted to Congress.

Presidential Powers: The foreign affairs powers of the president are based on Article II Section 1 of the Constitution that states that: "The executive Power shall be vested in a President of the United States of America."This provision has been interpreted as conferring foreign affairs powers on the president because, at the time that the US Constitution was drafted in 1787, the expression "executive Power" was interpreted as including powers over foreign affairs. ${ }^{4}$ On the basis of this interpretation of "executive Power," foreign affairs powers not explicitly identified in the Constitution as belonging to Congress belong to the president.
Congressional Porwers: However, there are in fact powers relating to foreign affairs that are explicitly identified in the Constitution as belonging to Congress. The Commerce Clause in Article I, Section 8 confers upon Congress the power "To regulate Commerce with foreign Nations, and among the several States, and with the Indian tribes." Further, the Treaty Clause in Article II Section 2 clause 2 of the Constitution confers upon the president the "Power, by and with the Advice and Consent of the Senate, to make Treaties, provided two thirds of the Senators present concur."

In summary, both the Commerce Clause and the Treaty Clause directly involve Congress in foreign affairs matters of the United States. The regulation of Commerce with foreign nations is expressly granted to Congress under the Commerce Clause. The president may make treaties only if "two thirds of the Senators present concur."

Crucially, the same article also includes the "Necessary and Proper Clause" (clause 18), which reads as follows:

"To make all Laws which shall be necessary and proper for carrying into Execution the foregoing Powers, and all other Powers vested by this Constitution in the Government of the United States, or in any Department or Officer thereof."

The "foregoing Powers" include the power of Congress to "regulate Commerce with foreign Nations" provided for in the Commerce Clause.

1 See https://piie.com/system/files/documents/piieb16-6.pdf.

2 Peterson study, page 7.

3 See "Congress can constrain only parts of Donald Trump's economic policy." The Economist. November 12, 2016 page 29.

4 See "The Textual Basis of the President's Foreign Affairs Power" by Michael D. Ramsey, page 141 http://www.law.harvard. edu/students/orgs/jlpp/Vol30_No1_Ramseyonline.pdf. 


\section{How Trade Agreements Are Implemented}

Under US law, trade agreements are now usually considered as Congressional/Executive Agreements rather than as treaties. ${ }^{5}$ This is because the president and Congress have joint authority over trade agreements, the president through the foreign affairs power (with limitations as discussed) and Congress through the Commerce Clause.

Trade agreements are negotiated by the Office of the United States Trade Representative ("USTR") and are signed by the president, but must be approved by Congress and implemented through implementing legislation enacted by Congress. NAFTA was approved under the North American Free Trade Agreement Implementation Act ("Implementation Act"), ${ }^{6}$ which Congress enacted under the authority of section 1103 of the Omnibus Trade and Competitiveness Act of $1988^{7}$ and section 151 of the Trade Act of $1974^{8}$, together with an accompanying Statement of Administrative Action. The latter is a statement that must be submitted to the House of Representatives and the Senate along with the implementing bill. It describes the administrative action proposed to implement a trade agreement. ${ }^{9}$ Congress expressly approved both NAFTA and the Statement of Administrative Action in Section 101(a) of the Implementation Act.

When Congress approves a trade agreement, Congress is approving terms upon which the commerce of the United States with the country or countries party to the agreement will be regulated. The act of approving a trade agreement falls squarely within the powers granted to Congress under the Commerce Clause.

\section{The Withdrawal Provision}

NAFTA Article 2205 reads as follows:

"A Party may withdraw from this Agreement six months after it provides written notice of withdrawal to the other Parties. If a Party withdraws, the Agreement shall remain in force for the remaining Parties."

In the case of the United States, the "Party" is the US government. Under the plain wording of NAFTA Article 2205, providing the written notice is simply a condition that a Party has to fulfil before it proceeds to withdraw from NAFTA. Providing the notice does not have the effect of causing a Party to withdraw from NAFTA. NAFTA does not provide any procedure for a Party to withdraw from NAFTA. This question is up to each Party to determine.

In approving NAFTA, Congress approved terms upon which the commerce of the United States with each of Canada and Mexico would be regulated, as Congress is expressly empowered to do under the Commerce Clause. If the United States withdraws from NAFTA, the terms upon which the commerce between the United States and each of Canada and Mexico will be regulated will be significantly altered. Absent an express legislative provision to the contrary, the provisions of NAFTA can only cease to have effect with

5 See "Why Certain Trade Agreements Are Approved as Congressional-Executive Agreements Rather Than Treaties," by Jane M. Smith, Daniel T. Shedd and Brandon J. Murrill, April 15, 2013, Congressional Research Service, 7-5700, www.crs. gov 97-896. This distinction between treaties and trade agreements is a purely US construct, arising from the separation of powers in the US Constitution. For international law purposes, such as for the application of the Vienna Convention on the Law of Treaties, trade agreements like NAFTA are treaties.

6 See 19 U.S.C. Chapter 21 North American Free Trade.

719 U.S.C. 2903.

819 U.S.C. 2191.

919 U.S.C §2903(a)(1)(B)(ii). 
respect to the United States if Congress repeals the Implementation Act. ${ }^{10}$

No mention is made in the Statement of Administrative Action of the procedure that would be followed if the United States wishes to withdraw from NAFTA. This statement also underscores that a notice given under NAFTA Article 2205 is merely a condition that must be completed before a Party withdraws and does not itself trigger the withdrawal of a Party.

Since NAFTA was approved by Congress under the authority expressly granted to Congress under the Commerce Clause, it follows that only Congress has the power to reverse that approval and cause the United States to withdraw from NAFTA.

While the president therefore does not have the unilateral power to take the United States out of NAFTA, the matter does not end there. As mentioned, there are many ways by which the President can frustrate or negate the benefits of NAFTA, to which I now turn.

\section{CAN THE PRESIDENT}

UNILATERALLY RAISE TRADE DUTIES ON NAFTA PARTNERS BY
PROCLAMATION?

The US Constitution also provides that the Congress shall have "Power To lay and collect Taxes, Duties, Imposts and Excises" (Article I, Section 8, clause 1). This means that only Congress has the power to impose duties and that the President can only impose duties by way of proclamation to the extent that Congress has delegated these powers to the president. There are numerous instances in which Congress has delegated to the president the power to impose duties, and in a number of these instances, the president has been allowed considerable discretion as regards the imposition of duties.

\section{Delegation of Proclamation Authority to the President in the Implementation Act}

A number of the provisions of NAFTA were implemented through proclamation by the president as opposed to being specifically spelled out in the Implementation Act. Section 201(a)(1) of the Implementation Act empowers the president to proclaim duties to carry out or apply a number of specific NAFTA provisions. ${ }^{11}$ Section 202(q) of the Implementation Act permits the president to proclaim certain matters respecting rules of origin. ${ }^{12}$

Implementing NAFTA provisions by way of presidential proclamation makes sense from a practical perspective. A number of NAFTA provisions respecting duties are expressed in terms of ranges rather than exact figures, and permit a certain degree of discretion. Other provisions contemplate revisions to rates of duties arising

10 There is no provision in the Implementation Act that empowers the president or any office of the administration to give a notice of withdrawal under NAFTA Article 2205, let alone effecting the withdrawal of the US government from NAFTA.

11 Article 302 and Annex 302.2 (tariff elimination), Article 305 (temporary admission of goods), 307 and Annex 307.1 (goods re-entered after repair and alteration), Article 308 and Annexes 308.1 and 308.2 (most-favoured-nation rates of duty on certain goods), Annex 300-B (provisions respecting textile and apparel goods) 703 and Annexes 703.2, and 703.3(certain agricultural goods).

12 The rules of origin are the rules for determining whether a good imported into one NAFTA country from another NAFTA country is eligible for NAFTA preferential tariff treatment. The rules generally require that materials incorporated into such a good that are imported from non-NAFTA countries be sufficiently transformed or have sufficient value added to them within the NAFTA countries so that good can be considered as "originating" and therefore eligible for NAFTA preferential duty treatment. 
from consultations between or among the NAFTA Parties. President Clinton gave effect to various NAFTA provisions by issuing Proclamation 6641 on December 15, $1993 .^{13}$

\section{Can the President Revoke Proclamation 6641 without Congressional Approval?}

The Peterson study contemplates the possibility of the president revoking Proclamation 6641, which brought a number of the duty-related provisions of NAFTA into effect. ${ }^{14}$ Proclamation 6641 was proclaimed under the authority of the Implementation Act and there is nothing in the Act that permits the president to revoke it. If Proclamation 6641 were revoked by the president before the Government of the United States had withdrawn from NAFTA, the tariff structure of the United States would be altered in a manner not sanctioned by Congress, which arguably would be in direct violation of the Commerce Clause.

Some have evoked Sub-section 125(b) of the Trade Act of 1974 as meaning that the President could revoke Proclamation 6641. This sub-section reads: "The President may at any time terminate, in whole or in part, any proclamation made under this Act." However, Proclamation 6641 was made pursuant to provisions of a number of Acts, including the Implementation Act that expressly provides for the tariff treatment provided for by NAFTA and to which Section 125(b) does not apply. Section 604 of the Tariff Act of 1974, which is cited in Proclamation 6641 and to which Section 125(b) does apply, provides authority for the technical changes to the U.S. tariff schedule effecting the NAFTA tariff treatment. Conceivably the president could revoke these technical changes, which would create difficulties for the administration of NAFTA and would provoke a major confrontation with Congress.

It could be argued more generally that the power to make a presidential proclamation implicitly includes the power to revoke it. If President Trump was to take such a position and revoke Proclamation 6641, a court action might well follow. In the interim, however, US administration could be obliged to comply with the presidential revocation and the old tariff structure could, at least temporarily, be in place.

\section{Duties under Section 201(b)}

Section 201(b) of the Implementation Act entitled OTHER TARIFF MODIFICATIONS is cited in the Peterson study as a potential basis for the imposition by the president of higher tariffs. The relevant parts of Section 201(b) for our purpose read as follows:

(1) IN GENERAL. - Subject to...the consultation and layover requirements of section 103(a), the President may proclaim -

$\cdots$

(D) such additional duties

as the President determines to be necessary or appropriate to maintain the general level of reciprocal and mutually advantageous concessions with respect to Canada or Mexico provided for by the Agreement.

The scenario contemplated in the Peterson study assumes that the president has exercised his authority over foreign affairs to cause the United

13 See https://en.wikisource.org/wiki/Proclamation_6641.

14 Peterson study, page 8. 
States to withdraw from NAFTA under NAFTA Article 2205. The president would then exercise the authority granted by Section 201((b) to cause duties to revert to higher rates.

There are problems with this scenario, because the wording of Section 201(b) itself, namely that duties or duty treatment proclaimed "be necessary or appropriate to maintain the general level of reciprocal and mutually advantageous concessions with respect to Canada or Mexico provided for by the Agreement (i.e., NAFTA)"15 presuppose that the US government has not withdrawn from NAFTA at the time that the proclamation power is exercised.

NAFTA sets out numerous requirements respecting duties and duty treatment. In expressly approving NAFTA, Congress approved the provisions of NAFTA respecting the imposition of duties. While Section 201(b) allows the president discretion in making proclamations respecting duties, that discretion does not extend to proclaiming duty treatment that is inconsistent with the duty treatment that Congress has approved under NAFTA. This seems to follow from the exclusive power of Congress respecting duties under the Commerce Clause.

\section{WHEN AND HOW CAN}

\section{CONGRESS DEFEND ITS POWERS? THE} POLITICAL QUESTION DOCTRINE

A unilateral attempt by President Trump to withdraw the government of the United States from NAFTA or to revoke Proclamation 6641 or to proclaim duties inconsistent with NAFTA under
Section 201(b) of the Implementation Act would raise serious constitutional issues respecting the respective powers of the president and Congress.

The decision by the US Supreme Court in Goldwater v. Carter ${ }^{16}$ underscores the importance to the governments of Canada and Mexico and to anyone else opposing the unilateral actions by the president just described of getting Congress actively involved in opposing such actions. In this case, Senator Barry Goldwater and other members of Congress challenged the right of President Jimmy Carter to unilaterally nullify the Sino-American Mutual Defense Treaty that the United States had signed with the Republic of China, so that relations could instead be established with the People's Republic of China. Senator Goldwater and his co-filers claimed that the president required Senate approval to take such an action, under the Treaty Clause and that, by not doing so, President Carter had acted beyond the powers of his office.

A majority of six ruled that the case should be dismissed without hearing an oral argument. In a concurring opinion, Justice Lewis Powell wrote that "a dispute between Congress and the President is not ready for judicial review unless and until each branch has taken action asserting its constitutional authority," adding "If the Congress chooses not to confront the President, it is not our task to do so." In other words, the Court needs to let political questions resolve themselves in the political arena, based on political considerations, until a constitutional impasse is reached and one branch or another formally asserts its authority in court.

15 The Peterson study (on page 8) characterizes the "general level of reciprocal concessions" as "fuzzy legal terminology." The language is much less "fuzzy" when read together with the words that follow, namely "with respect to Canada and Mexico provided for by the Agreement." The whole point of NAFTA was to provide reciprocal concessions among the Parties. There is nothing in this language that could justify the proclamation of a duty that was inconsistent with the requirements of NAFTA.

16444 U.S. 996 (1979). 
Based on the so-called "political question doctrine" exemplified by this case, if the president attempts to withdraw the United States from NAFTA without Congressional consent, or if the president purports to revoke Proclamation 6641, each of the House of Representatives and the Senate could pass resolutions objecting to the presidential action. If President Trump attempted to use Section 201(b) of the Implementation Act described above to raise duties, the committees referred to in the consultation and layover requirements in Section 103 of the Implementation Act that must be consulted before action is taken under Section 201(b) must be persuaded to strongly object to such action.

The essential point is that there must be a sufficient level of Congressional objection so that a court will not simply wash its hands of the matter based on the political question doctrine and refuse to make a decision.

As Canadian trade negotiators and Canadian diplomats are well aware, dealing with Congress is not easy. Representatives and Senators often take different approaches to issues and members of the same party in each of the House and the Senate may have very different views and priorities. Achieving a co-ordinated approach from the House and the Senate will require a great deal of skill, persistence and attention.

It should also be kept in mind that while Congress can defend its powers by enacting a bill, the president can object to the bill, which will not then become law unless repassed by two-thirds of each of the House of Representatives and the Senate. ${ }^{17}$

\section{WHAT OTHER PRESIDENTIAL POWERS COULD BE USED TO FRUSTRATE NAFTA?}

Provided that Canada and Mexico have strong support of Congress, Canada and Mexico may be able to resist an attempt by President Trump to unilaterally withdraw the United States from NAFTA or to revoke Proclamation 6641 or to impose NAFTA-inconsistent duties under Section 201(b) of the Implementation Act.

However, the president has formidable powers to initiate action on the trade front that could seriously frustrate the functioning of NAFTA, possibly to the extent of rendering it inoperative, and that could be used to force concessions from Mexico and Canada, as well as from other trading partners of the United States.

The Peterson study identifies a number of statutes under which powers to levy duties have been delegated to the president to address trade deficits, national emergencies, national security situations and various other issues. ${ }^{18}$

\section{Trade Act of 1974, Section 122}

Section 122 of the Trade Act of $1974^{19}$ permits the president to proclaim a temporary import surcharge, not to exceed 15 percent ad valorem, in the form of duties (in addition to any duties already imposed) on articles imported into the United States to deal with large and serious US balance-of-payments deficits. $^{20}$

The trade restrictions sanctioned under this legislation are supposed to be applied on a non-

17 US Constitution, Article I Section 7.

18 See Table 1.1 on page 6 of the Peterson study that lists these statutes and briefly summarizes the presidential powers under each.

19 Codified as 19 U.S.C $\$ 2132$.

20 See the Peterson study, pages 10-11. See also 19 U.S.C §2132(a)(1). 
discriminatory basis. ${ }^{21}$ However, if the president determines that the purposes of the legislation will best be served by action against one or more countries having large or persistent balance-ofpayments surpluses, the president may exempt all other countries from such action. ${ }^{22}$

\section{Trade Expansion Act of 1962, Section 232(b)}

Section 232(b) of the Trade Expansion Act of 1962 provides for the investigation by the Secretary of Commerce to determine the effects on national security of imports of articles identified in the request for an investigation. ${ }^{23}$ The request may be made by the head of any department or by any interested party or by the Secretary of Commerce on his own initiative. If the secretary finds that the articles are being imported in quantities or under circumstances that threaten to impair national security, the Secretary must determine whether the President concurs. If the president does concur, the president can implement various actions to adjust the level of imports.

The president has pretty wide discretion in determining what constitutes a national emergency and the Peterson study points out that US courts defer to executive branch determinations of national security. ${ }^{24}$

\section{Trade Act of 1974, Section 301}

These statutory provisions can be applied if a foreign country denies the United States its rights under free trade agreements or carries out practices that are unjustifiable, unreasonable, or discriminatory, and permits retaliatory actions, at presidential discretion, including tariffs and quotas. ${ }^{25}$ Section 301 investigations can result from a petition filed by an industry or can be selfinitiated by the USTR. ${ }^{26}$ The legislation sets out extensive actions that can be taken by the USTR including suspension of benefits under a trade agreement such as NAFTA and the imposition of such duties or other import restrictions as the USTR considers appropriate. ${ }^{27}$ The president has considerable discretion to direct the USTR on what actions to take. $^{28}$

Section 301 and related provisions were considered by a WTO panel in United States - Sections 301-310 of the Trade Act 1974. ${ }^{29}$ The WTO panel observed that the Statement of Administrative Action approved by Congress in connection with the legislation implementing US WTO obligations committed the USTR to base any Section 301 determination of a violation or denial of US rights under a WTO agreement on panel or Appellate Body findings adopted by the WTO Dispute Settlement Body. ${ }^{30}$ The WTO panel

2119 U.S.C $\$ 2132(\mathrm{~d})(1)$.

2219 U.S.C $\$ 2132(\mathrm{~d})(2)$.

23 19 U.S.C $§ 1862($ b). These provisions are described in the Peterson study pages 9 to 10. See also Section 232 Investigations - Program Guide set out at https://www.bis.doc.gov/index.php/forms-documents/section-232-investigations/86-section232-booklet/file.

24 Peterson study, page 10.

25 Ibid., page 11.

26 Section 301 is codified as 19 U.S.C \$2411.

2719 U.S.C \$2411(c).

2819 U.S.C \$2411(a).

29 Dispute DS 152.

30 Panel report paragraph 7.1115. 
accepted this commitment as a basis for a finding that there was no violation by the United States of its WTO obligations. ${ }^{31}$

The Peterson study observes (p. 11) that the commitment in this Statement of Administrative Action is not codified into US law. Also, it stated there is no corresponding commitment in the Statement of Administrative Action approved by Congress in connection with NAFTA. In fact, the NAFTA Statement of Administrative Action makes it clear that Section 301 remains fully available if another NAFTA country engages in practices that burden or restrict US commerce. Also, Section 102(a)(2)(B) of the Implementation Act provides that nothing in the Implementation Act will "limit any authority conferred under any law of the United States, including section 301 of the Trade Act of 1974." This broad language covers the other US statutes referred to in addition to Section 301.

\section{Trading with the Enemy Act of 1917}

These statutory provisions confer broad powers on the president to take actions during war and during national emergencies that can include trade sanctions. ${ }^{32}$ Section $5(\mathrm{~b})$ of this legislation confers broad powers upon the president to investigate, regulate, nullify, void and prohibit a wide range of commercial transactions that include the regulation of importation. The original language, which was confined to during time of war, was expanded in 1977 to include periods of national emergency. ${ }^{33}$

As noted above, the president has broad discretion to determine what constitutes a period of national emergency. Section 5(b) of the Trading with the Enemy Act of 1917 was used to justify the imposition of the 10 percent surcharge by President Nixon in 1971 and this use of the statute for this purpose was upheld in United States v. Yoshida Intern., Inc. ${ }^{34}$

On the subject of surcharges, members of the Trump team have raised objections to the fact that countries with value-added taxes do not impose these taxes on exports but levy such taxes on imports. Canada has not been mentioned but Canadian GST/HST operates in this manner. The objection misses the point that these types of taxes are taxes on consumption and their burden falls on the consumer who purchases goods for his/her own consumption. GST/HST paid on imports that are used in a business, such as inventory or capital goods, is refunded. A surcharge in the form of a border adjustment tax, or changes to US corporate income taxes to exempt earnings from exports but tax companies more for importing (such as by not allowing a deduction of the cost of imports), which is being floated as a way to counteract this aspect of value-added taxes in other countries, would constitute an export subsidy. Such a move would also be openly discriminatory against imports and would put the US at odds with virtually all of its trading partners, while having dubious impact on US competitiveness (See, among other economic commentary on these types of measures, CRS 2009).

\section{International Emergency Economic Powers Act of 1977}

This statute also covers war situations and national emergency situations. ${ }^{35}$ The powers set out in this

31 Panel report paragraphs 7.133 and 7.134.

32 These are outlined in the Peterson study, pages 11 to 13.

33 See U.S.C. Title 50 Appendix - War and National Defence, which sets out the text of Section 5(b). The original language referred only to time of war but this language was expanded by Pub. L. 95-223, §§101(a), 102 to include "other period of national emergency."

34526 F.2d 560, 572 (C.C.P.A. 1975). For the text of this case, see https://casetext.com/case/united-states-v-yoshida-intern-inc.

35 Codified at 50 U.S.C. $\S \S 1701$ through 1706. The Peterson study discusses this legislation on pages 13 to 14. 
legislation may only be used to deal with an unusual and extraordinary threat having its source in whole or substantial part from outside the United States, in respect of which the president has declared a national emergency. ${ }^{36}$ Once the national emergency is declared, the president has extensive powers to regulate a wide range of commercial transactions. ${ }^{37}$ There are provisions requiring that the President consult with and report regularly to Congress. ${ }^{38}$

The Peterson study points out that President Trump's exercising these powers to deal with the sort of trade complaints that he has raised would be "vigorously challenged" as a massive usurpation of Congressional power. ${ }^{39}$ This challenge would be balanced against the discretion that has historically been allowed to the president in determining what constitutes a national emergency.

The president and his administration can also pressure trading partners through administrative steps at the border. US officials can use their discretion to conduct lengthier and more frequent inspections of goods at US border crossings to make accessing the US market more difficult. The border between the United States and each of Canada and Mexico thickened substantially after $9 / 11^{40}$ and a wilful US administration wishing to apply pressure could apply a range of procedures to make trade more difficult, notwithstanding significant progress in recent years to simplify border crossing for safe trade and passenger travel between the two countries.

\section{THE FOCUS ON MEXICO - WHAT ARE THE IMPLICATIONS FOR CANADA?}

Judging from statements made by some of Mr. Trump's advisors, the incoming Trump Administration appears to be particularly concerned about large US trade deficits with Mexico and China.

Mr. Trump is clearly concerned personally about US companies' offshoring jobs to Mexico. He has said repeatedly, both during the election campaign and after becoming the president-elect that US companies that offshore jobs to Mexico will suffer consequences such as 35 percent tariffs when they import their Mexican-produced goods into the United States. Withdrawing from NAFTA will not solve US balance of payments and offshoring issues with Mexico. However, President Trump could attempt to address the issues he has identified regarding Mexico through invoking powers of the president under one or more of the statutes described above.

The US trade deficit with Canada should not be an issue for the Trump Administration, ${ }^{41}$ and US companies do not offshore jobs to Canada in search of cheap labour. Nor do other issues besetting the US-Mexico relationship, notably that of illegal migration, directly affect Canada in the same way.

However, Canada is at risk of being side-swiped if the Trump Administration chooses to take trade

3650 U.S.C. $§ 1701$.

3750 U.S.C. $\$ 1702$.

3850 U.S.C. $§ 1703$.

39 Peterson study, page 13.

40 See, for example, W. Mark Brown, 2015, How Much Thicker is the Canada-U.S. Border? The Cost of Crossing the Border by Truck in the Pre- and Post 9/11 Eras, Statistics Canada online catalogue \#11F0027M no.99.

41 The US trade deficit with Canada for the 12 month period from October 1, 2015 through to September 30, 2016 amounted to a little over $\mathrm{C} \$ 28$ billion. This amounted to only 3.78 percent of the total two-way trade between Canada and the United States during this period and probably is entirely accounted for by the large volume of oil that Canada exports to the United States. For these figures, see http://www5.statcan.gc.ca/cansim/a26?lang=eng\&retrLang=eng\&id=3760110\&\&patte rn=\&stByVal=1\&p1=1\&p2=31\&tabMode=dataTable\&csid. 
actions against other US trading partners with whom trade deficits and offshoring are issues. This would be in addition to the likelihood that the fresh countervailing duty actions by the US lumber industry based on the claim that "stumpage fees" paid for logs harvested from provincial crown lands are too low-despite binational panels having consistently found that stumpage fees in Canada do not constitute subsidies - will feed into the narrative that the United States is a victim of the unfair trading practices of its trading partners.

In that light, the fact that the bilateral CanadaUnited States Free Trade Agreement (CUSFTA), which came into effect on January 1, 1989 is only dormant under NAFTA and could provide a backstop for Canada should NAFTA unravel, is of only limited comfort. Reverting to the bilateral deal would involve a lot of complications - not least reverting to CUSFTA rules of origin, and very different services and investment chapter provisions.

Canada, therefore, is better off remaining open to any proposals by the new US Administration regarding NAFTA, in light of the very real potential for actions by the US president that could severely disrupt North American trade in the shorter term. Indeed, as the dynamics of Mexican response to the new US policy direction will likely affect Canada one way or another (for example through their impact on manufacturing value chains or temporary migration flows), Canada should prefer a trilateral approach to the resolution of issues between the United States and Mexico, where this makes sense, in the same way that it was better for Canada to promote NAFTA than to have the United States sign two separate bilateral trade deals with its immediate neighbours. At the same time, Canada should redouble its efforts to persuade Congress, which holds more potential constitutional sway in the medium-term, that trade with Canada, in the context of NAFTA, is beneficial to the United States. Potential reliance on the CUSFTA is clearly a second best scenario, albeit one that can be evoked to strengthen Canada's position in any NAFTA renegotiation. ${ }^{42}$

\section{Emphasizing the Cost to the United States of Trade Actions}

As indicated above, the president has formidable powers to initiate action on the trade front to apply pressure on trading partners of the United States. However, the application of any of these powers is not free of risk to the United States.

Supply chains will be disrupted and US workers may be laid off or could lose their jobs permanently. Restricting supply from the major source of softwood lumber imported into the United States, namely Canada, will increase margins charged by US softwood lumber producers but will hurt both the US construction industry and US home buyers. ${ }^{43}$ The application of statutory powers by the president to impose duties could be challenged by Congress and in the US courts. Trading partners of the United States will retaliate, either by invoking dispute settlement procedures under the WTO or under other trade agreements, or simply resorting to self-help by erecting trade barriers against US goods.

42 The more recent petitions filed by the US industry have alleged dumping as well as subsidization.

43 Mention has also been made of the reinstatement by the United States of country of origin labelling requirements for meat products. These rules resulted in considerable hardship to Canadian cattle producers because U.S. meat processors had to keep cattle imported from Canada separate from U.S. cattle throughout processing, which was not commercially practical. WTO panels found this practice inconsistent with WTO rules and the U.S. Government recently revoked these requirements. Re-imposing these requirements would increase U.S. processing costs and potentially hurt workers employed in the U.S. meat processing sector, as well as U.S. consumers. 
Trade retaliation sanctioned through WTO dispute settlement procedures can be very costly. For example, in the United States - Tax Treatment for "Foreign Sales Corporations," an arbitrator authorized the suspension by the European Communities (now the European Union) of 100 per cent ad valorem charges on imports of certain goods from the United States in a maximum amount of over US $\$ 4$ billion. ${ }^{44}$

Members of Congress will be sensitive to damage suffered by companies operating within their Congressional districts or states and to jobs lost by their constituents. This is why a sensible strategy for Canada should be to highlight these issues for members of Congress, in the hope that they could blunt at least some of the more damaging anti-trade policies that the Trump Administration may consider pursing.

\section{CONCLUSION}

Both candidate Trump and President-Elect Trump repeatedly stated that NAFTA must be renegotiated or terminated. While the negative statements have been directed at Mexico rather than Canada, the governments of both Canada and Mexico must be prepared for the possibility that President Trump will act on his statements.

It is important that the question as to whether President Trump can unilaterally precipitate a US withdrawal from NAFTA be answered because the dynamics of any renegotiation of NAFTA will be significantly affected by the answer. If President Trump can cause the United States to unilaterally withdraw from NAFTA on six months' notice, Canadian and Mexican negotiators will be under enormous pressure to give in to US demands if they want to salvage NAFTA. If only Congress can cause the United States to formally withdraw from NAFTA, Canadian and Mexican negotiators will not be under a short deadline to agree or risk losing NAFTA and will be in a somewhat stronger bargaining position.

As shown in this paper, the ultimate power to withdraw from NAFTA rests with the United States Congress, and not with the president. Nor can the president unilaterally terminate Proclamation 6641 or impose duties inconsistent with NAFTA requirements under section 201(b) of the NAFTA Implementation Act without impinging on the powers of Congress.

However, very disruptive unilateral actions could be taken in the meantime by the president and the US administration, including border delays and increased inspections and other steps to thicken the border. Some of those potential actions would raise serious legal constitutional issues in the United States and as such would likely be challenged in US Court. However, the ultimate resolution of those challenges would likely take a long time. It may well be that rather than starting with something draconian (like purporting to withdraw), the USTR will contact the respective governments of Canada and Mexico and put forward a list of demands. There is a real problem for Canada in that Trump's rhetoric has been entirely directed at Mexico and it can be difficult to visualize what shape a renegotiation based on addressing these issues would take with respect to Canada. Nevertheless, Canada must be prepared to sit down with the new US Administration and the Government of Mexico to discuss changes the former will want to make the NAFTA.

44 See United States - Tax Treatment for "Foreign Sales Corporations" Recourse to Arbitration by the United States under Article 22.6 of the DSU and Article 4.11 of the SCM Agreement, Decision of the Arbitrator, https://www.wto.org/english/ tratop_e/dispu_e/108_arb_e.pdf. 
At the same time, Canada, as well as Mexico, must play the long game and determine what can be done, both within the U.S. judicial system and through international bodies such as the WTO to resist such actions. The Governments of Canada and Mexico should also secure as much support in both the House of Representatives and the Senate as possible from representatives and senators who support free trade and whose constituents will be hurt by aggressive anti-trade policies pursued by the Trump Administration. 


\section{REFERENCES}

Brown, Mark W. 2015. "How Much Thicker is the Canada-U.S. Border? The Cost of Crossing the Border by Truck in the Pre- and Post 9/11 Eras." Statistics Canada online catalogue \#11F0027M no. 99 .

Congressional Research Service. 2009. "International Competitiveness: An Economic Analysis of VAT Border Tax Adjustments." Accessed at: https:// www.everycrsreport.com/files/20090730_R40735_ e897144e0fbd77d601e7fbfd853e90276adf280e.pdf.

Johnson, Jon R. 1994. The North American Free Trade Agreement: A Comprehensive Guide, Canada Law Book Inc.

Noland, Marcus, Gary Clyde Hufbauer, Sherman Robinson, and Tyler Moran. 2016. "Assessing Trade Agendas in the US Presidential Campaign" (the Peterson study). Washington: Peterson Institute for International Economics.

Ramsey, Michael D. 2006. "The Textual Basis of the President's Foreign Affairs Power." Harvard Journal of Law E Public Policy. Vol. 30. Accessed at http:// www.law.harvard.edu/students/orgs/jlpp/Vol30_ No1_Ramseyonline.pdf

Smith, Jane M., Daniel T. Shedd, and Brandon J. Murrill, 2013. "Why Certain Trade Agreements Are Approved as Congressional-Executive Agreements Rather Than Treaties." Congressional Research Service, 7-5700, www.crs.gov 97-896. 
NOTES: 


\section{ReCent C.D. Howe institute Publications}

January 2017 Sutherland, Jason M., and Erik Hellsten. Integrated Funding: Connecting the Silos for the Healthcare We Need. C.D. Howe Institute Commentary 463.

January 2017 Guo, Huijie, and David R. Johnson. "Unfair Advantage? School Fundraising Capabilities and Student Results.” C.D. Howe Institute E-Brief.

December 2016 Cross, Philip. What do the Different Measures of GDP Tell Us? C.D. Howe Institute Working Paper.

December 2016 Dodge, David A. "The Role of Macro-Economic Policies in an Era of Global Economic Stagnation.” C.D. Howe Institute Verbatim.

December 2016 Busby, Colin, and Ramya Muthukumaran. Precarious Positions: Policy Options to Mitigate Risks in Non-standard Employment. C.D. Howe Institute Commentary 462.

November 2016 Schwanen, Daniel, Jeremy Kronick, and Ramya Muthukumaran. Playing from Strength: Canada's Trade Deal Priorities for Financial Services. C.D. Howe Institute Commentary 461.

November 2016 Dachis, Benjamin, William B.P. Robson, and Jennifer Y. Tsao. Two Sets of Books at City Hall? Grading the Financial Reports of Canada's Cities. C.D. Howe Institute Commentary 460.

November 2016 Geraghty, Sharon C. “Takeover Rules: In Support of the Longer Minimum Bid Period.” C.D. Howe Institute E-Brief.

November 2016 Ambler, Steve. "Putting Money to Work: Monetary Policy in a Low Interest Rate Environment." C.D. Howe Institute E-Brief.

October $2016 \quad$ VanDuzer, J. A. Investor-state Dispute Settlement in CETA: Is it the Gold Standard? C.D. Howe Institute Commentary 459.

October 2016 Kronick, Jeremy, et Alexandre Laurin. "Une vision globale : Comment le quatrième pilier affecte la préparation à la retraite» Institut C.D. Howe Commentaire $\mathrm{N}^{\circ} 457$.

October 2016 Spicer, Zachary, and Adam Found. Thinking Regionally: How to Improve Service Delivery in Canada's Cities. C.D. Howe Institute Commentary 458.

\section{SUPPORT THE INSTITUTE}

For more information on supporting the C.D. Howe Institute's vital policy work, through charitable giving or membership, please go to www.cdhowe.org or call 416-865-1904. Learn more about the Institute's activities and how to make a donation at the same time. You will receive a tax receipt for your gift.

\section{A REPUTATION FOR INDEPENDENT, NONPARTISAN RESEARCH}

The C.D. Howe Institute's reputation for independent, reasoned and relevant public policy research of the highest quality is its chief asset, and underpins the credibility and effectiveness of its work. Independence and nonpartisanship are core Institute values that inform its approach to research, guide the actions of its professional staff and limit the types of financial contributions that the Institute will accept.

For our full Independence and Nonpartisanship Policy go to www.cdhowe.org. 

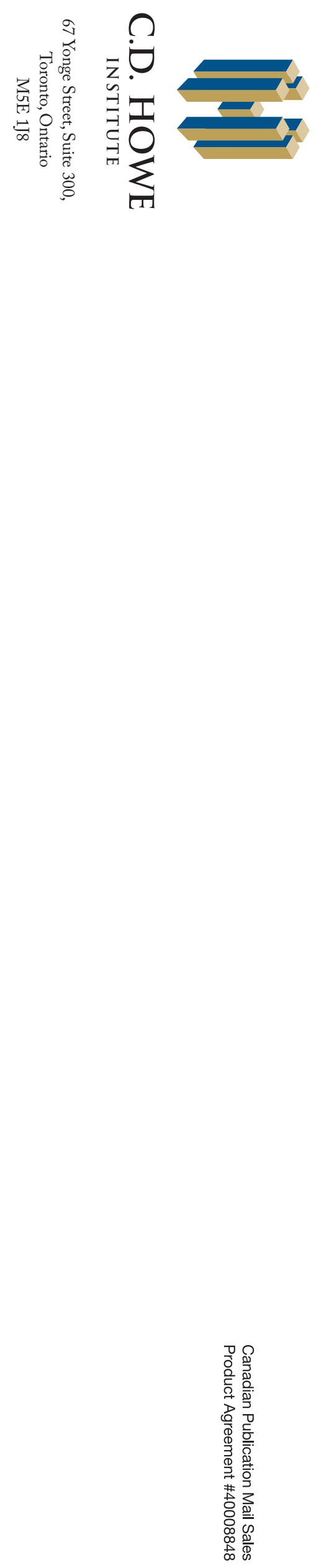